Paideusis

\title{
A Critique of Anti-heterosexist Curriculum and Student Consent at the Toronto District School Board
}

\section{Jair Matrim}

Volume 22, Number 1, 2014

Sexual and Gender Diversity in Schools

URI: https://id.erudit.org/iderudit/1071466ar

DOI: https://doi.org/10.7202/1071466ar

See table of contents

Publisher(s)

Canadian Philosophy of Education Society

ISSN

0838-4517 (print)

1916-0348 (digital)

Explore this journal

Cite this article

Matrim, J. (2014). A Critique of Anti-heterosexist Curriculum and Student Consent at the Toronto District School Board. Paideusis, 22(1), 60-70.

https://doi.org/10.7202/1071466ar
Article abstract

Efforts to embed anti-heterosexist curriculum at the Toronto District School Board (TDSB) can become confused and contradictory because of the persistent subjection of the student to the curriculum, and by maintaining sex as a subject of danger and prohibition. Examples from the new TDSB anti-discrimination curriculum resource that were perceived as politically controversial in 2011 are briefly assessed with the popular queer(ed) theories of Foucault (1978/1990), Butler (1990; 1993), and Rubin (1984/1993). Deleuze's (1988) interpretation of Spinoza's work is also plumbed to explain the consequences of heterosexist discourse in schools. The Deleuzian-Spinozan example of the caricatures of the "moralist trinity" shows that heterosexist discourses promote the production of "sad passions" throughout social relationships by creating "sad" characters within each individual. Finally, anti-heterosexist action in schools is described as modelling consent in curriculum and exposing relationships of subjection.
This document is protected by copyright law. Use of the services of Erudit (including reproduction) is subject to its terms and conditions, which can be viewed online.

https://apropos.erudit.org/en/users/policy-on-use/ 
Paideusis, Volume 22 (2014), No. 1, pp. 60-70

\title{
A Critique of Anti-heterosexist Curriculum and Student Consent at the Toronto District School Board
}

\author{
JAIR MATRIM
}

Efforts to embed anti-heterosexist curriculum at the Toronto District School Board (TDSB) can become confused and contradictory because of the persistent subjection of the student to the curriculum, and by maintaining sex as a subject of danger and probibition. Examples from the new TDSB anti-discrimination curriculum resource that were perceived as politically controversial in 2011 are briefly assessed with the popular queer(ed) theories of Foucault (1978/1990), Butler (1990; 1993), and Rubin (1984/1993). Deleuze's (1988) interpretation of Spinoza's work is also plumbed to explain the consequences of heterosexist discourse in schools. The Deleuzian-Spinozan example of the caricatures of the "moralist trinity" shows that heterosexist discourses promote the production of "sad passions" throughout social relationships by creating "sad" characters within each individual. Finally, anti-heterosexist action in schools is described as modelling consent in curriculum and exposing relationships of subjection.

\section{Progress at the Toronto District School Board for Sexual and Gender Minorities}

The Toronto District School Board (TDSB) is the largest school board in Canada, and the fourth largest in North America. Its almost 600 secular, public schools serve over 250,000 students annually. In 2000, the board adopted the new anti-discrimination policy Equity Foundation Statement \& Commitments to Equity Policy Implementation (TDSB, 2005; Matrim, 2014). Different from earlier anti-discrimination policies in Ontario, the board committed itself to the development of anti-heterosexist and anti-homophobic curriculum.

No studies have measured the impact of this policy on students, but the 2006 TDSB Student Census (Yau \& O’Reilly, 2007) and the 2011 TDSB Student Census (Yau and O'Reilly, 2012) asked students if they had heard about the experiences and achievements of "lesbian, gay, and transgendered" people in school curriculum. ${ }^{1}$ The 2011 study revealed that $51 \%$ of surveyed TDSB students between Grades 9 and 12 had "rarely or never" heard about the experiences and achievements of lesbian, gay and transgendered people in the curriculum.

\footnotetext{
${ }^{1}$ In both studies, only students above the Grade 9 level were asked to answer this question, thus avoiding the mere mention of lesbian, gay, and transgendered people to those in lower grades.
}

(C) Copyright 2014. The author, Jair Matrim, assigns to Paideusis the right of first publication and educational and non-profit institutions a non-exclusive license to use this document for personal use and in courses of instruction provided that the article is used in full and this copyright statement is reproduced. Any other usage is prohibited without the express permission of the author. 


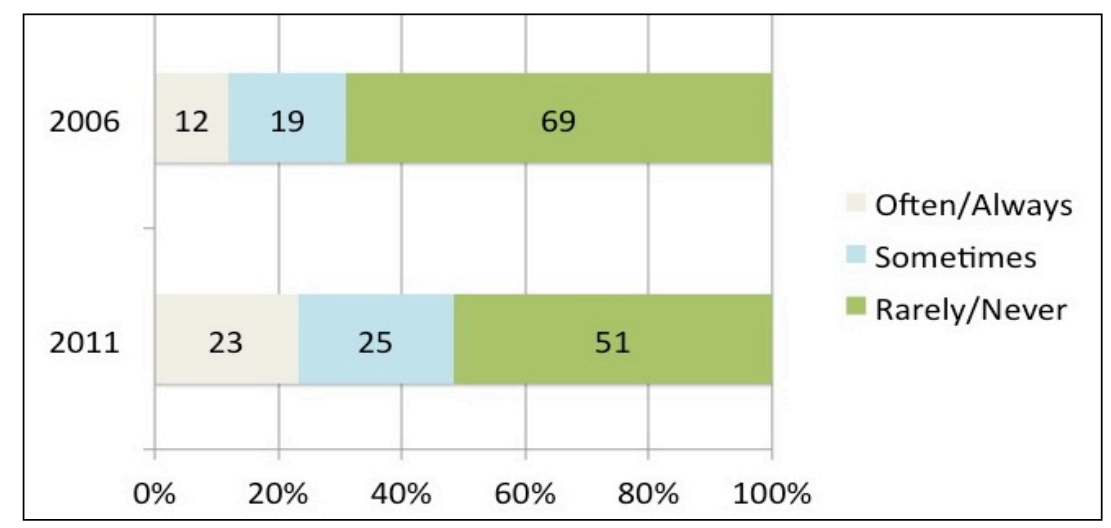

Figure 1: Students who "learned about the experiences and/or achievements of lesbian, gay, and transgendered people”. TDSB Student Census (Yau et al., 2007, 2013)

Sex and gender minorities are represented more often in curriculum in 2011 than in 2006. Without a measurement that could tease out what counts as "rarely" and what counts as "never", it is difficult to make a definitive statement about the representation of lesbian, gay, and transgendered people in curriculum. Between 2007 and 2009, student-aged youth in Toronto and across Ontario also reported a need to learn more about healthy relationships, noting that there is a negative, evasive, and prohibitive treatment about puberty and sexually-transmitted diseases (Flicker et al., 2009; Safe Schools Action Team, 2008). Generally, any education related to sex and sexuality is lacking across the province, and the inadequate frequency of representing sex and gender minorities in the curriculum is part of this problem (Matrim, 2014).

Policy makers at the TDSB tried to improve the curriculum by promoting the inclusion of sex and gender minorities, but attempts at inclusion must also navigate a dense gauntlet of both real and imagined harms to the child-student in school spaces. The ongoing phenomenon of heterosexist exclusion, sex negativity, avoidance, and censorship is situated in an historical struggle over what counts as "good" sex, the protection of children, and the appropriate and/or legitimate use of pedagogical authority. I examine some of the more recent and problematic anti-discrimination curriculum that the TDSB has developed to include sex and gender minorities. Specifically, I examine a political controversy that took issue with a new TDSB antidiscrimination curriculum. Using the political controversy as a reference, and guided by theoretical accounts of sex and gender developed by Michel Foucault (1978/1990), Judith Butler (1990, 1993), and Gayle Rubin (19883/1993), I will briefly assess how some of the new anti-discrimination curriculum works to affect an understanding of sex and sexuality among individual students.

The term "consent" has also circulated on Canadian university campuses recently in response to a "rape culture". Several incidents involving sexual assaults and rape chants have become high-profile issues across Canada in 2013-2014. "Got Consent?" has been part of the promotional material from such organizations as the Sexual Assault Support Centre at the University of British Columbia. The concept of acquiring "consent" may also work broadly to identify what is most relevant about sex, identity politics, sexuality, and sexual relations in high-school curricula. The subjection of students to a hierarchical curriculum that typically excludes sex and gender minorities raises some difficult questions about how Canadian schools can change more effectively. How does this non-consenting relationship between students and the curriculum affect how students learn about sex, sexuality, heterosexism, and homophobia? Is it possible that a practice of negotiated "consent" within the curriculum might also work to bolster a more positive and inclusive education related to sex and sexuality? Exploring the broad application of this principle of consent, I analyze how students do or do not consent to their subjectivity as an 'identity' that is situated within heterosexist discourses, and as a student subjected to school curriculum. I assess how these relationships might have an impact on their development. To undertake this analysis, I use a metaphor from $17^{\text {th }}$ century philosopher Baruch Spinoza as interpreted by Gilles Deleuze (1988) which invokes a trinity of three caricatures of the sad passions: the tyrant, the priest, and the slave. The metaphor is especially useful for a outlining the consequences of a life of subjection. These caricatures explore the production of the "...internal death, [and] the universal sado-masochism of the tyrant-slave” relationship (Deleuze, 1988, p. 12, 13). The metaphor helps 
to specify the real dangers that are presented in a heterosexist and homophobic curriculum, and points to the practical necessity for attaining student consent in all matters related to the school curriculum-especially for addressing sex, gender identity, and/or sexuality. This metaphor provides a type of proof for why teaching and modelling consent with matters related to sex and sexuality are necessary for curriculum in heterosexist conditions.

\section{A Controversial Anti-Heterosexist Curriculum}

The TDSB attempted to fill a significant gap in provincial curriculum by developing its own resources to include sexual and gender minorities (Matrim, 2014). One significant resource was called the Rainbow and Triangles: A Curriculum Document for Challenging Homophobia and Heterosexism in the K-6 Classroom (Toronto District School Board \& Elementary Teachers of Toronto, 2002). A second revision was released nearly a decade later in 2011 under a new title Challenging Homophobia and Heterosexism: A K-12 Curriculum Resource (CH\&H) (Toronto District School Board, 2011). The second edition of $\mathrm{CH} \& \mathrm{H}$ became a subject of political controversy during the Ontario provincial election in the fall of 2011. The Ontario Progressive Conservatives released a flyer during the campaign that claimed that this resource had gone too far. "Cross-dressing for sixyear olds", reclaiming Valentine's Day with a "kissing booth", reading "some traditional folk tales and fairy tales with the class", and having "students write their own 'gender-bending' versions" for these traditional fairy tales were all identified as problems.

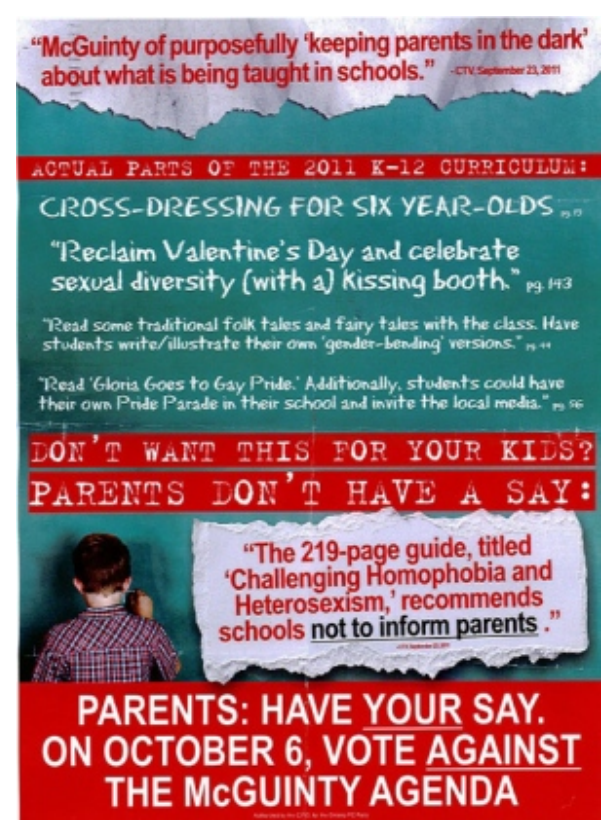

Figure 2: The Canadian Press. (2011, October 3). Retrieved March 3, 2014, from CBC News: http://www.cbc.ca/news/canada/toronto/story/2011/10/03/ontario-parties-campaignminority $274 . \mathrm{html}$

The panic communicated by the political flyer was partly rhetorical because it did not specify why or how instructional techniques such as gender role-play are bad for students. Rather, by taking issue with roleplay games at the expense of including sex and gender minorities, the text of the flyer might suggest that any critical or first-person play with gender roles, sharing of affection, or mention of sexual diversity would harm students.

The CH\&H resource offers many activities that allow students to experiment and question sex and gender roles and their connection to heterosexist assumptions. Far from constituting a challenge to any 
development of heterosexual desire, substituting characters in heterosexist fairy tales with diverse sex and gender identities, "cross-dressing", and role-play activities may equally work to affirm heterosexual desire rather than challenge or undermine its privilege as a dominant norm. Butler $(1990,1993)$ has argued that separating performances of gendered identity and sexual desire from universalizing categories, denaturalizing sex and gender identifications, and revealing the implicit strategy at play in gendered performances all have been useful challenges to the dominant order of compulsory gendered performances of heterosexuality in sex and gender minority communities. In proposing this, Butler (1993) conceives of gender as a social performance that becomes repeated, re-enacted, and appears as normal and natural under the auspices that heterosexual sex is the "origin of all sex" (p. 318). Experimenting with and questioning gender roles, however, does not necessarily expose a child to harmful messages. This play may allow students a space in which to explore the consequences of these roles. Role-play activities might also help to prepare students to question dominant social norms and enter into discussions about stereotypes. This critical exploration can help to reduce the chance of persecution and violence for all students.

The political flyer appears to have a more general problem with the notion that anything about sex, sexuality, or gender is to be taught at all. New policy and curriculum at the TDSB have proposed some ways to be more representative of minorities in curriculum, but some of these efforts have been at the expense of developing a more positive discourse about sex for all students (Matrim, 2014). A problem with any attempt to develop a more positive discourse about sex is that it is not clear in any curriculum policy what might count as a more positive and healthy account of sexuality for all students.

Foucault (1978/1990) describes sex as a discourse of power that has been developing over several millennia and that has a very specific history in the West, characterized by treating everything related to sex and sexuality as something that requires social control. Foucault points out that when we speak of "sex", we have already deployed the imagined boundaries of this concept and have separated selected acts and desires from the rest of our experience, as if these acts have a distinct truth, or a cause and effect paradigm of their own. Foucault identifies some of the "polymorphous techniques of power" that have shaped an understanding of what might count as sex and sexuality. This is not about uncovering an essential truth about sex, but rather creating a view of how sex has been brought into contemporary thought by a "will to knowledge" (pp. 11, 12). ${ }^{2}$

Sex has been distinguished in particular ways, put into speech, and this discourse represents a particular form of control and power in individual lives. The specific problem for Foucault $(1978 / 1990)$ is that the activities of the body, "sex" in particular, has been realized as if it is a force of its own, distinct from everything else, and as a moral test, judged by authorities, deserving of confession, and thought to inspire repression. Foucault's central argument is that sex does not require any liberation from repression, since its possibility as a practice has also been constituted by its moral prohibitions. Desire becomes a strategy of resistance against various hierarchical concepts, such as the stratification of gender, sexualities, sex acts, and desires as good or evil, unchanging, and universal (Rubin, 1984/1993) ${ }^{3}$. The circulation of heterosexist

\footnotetext{
2 Foucault does not investigate sex as if it were only a reproductive capacity, or as if sex is only determined by reproductive outcomes. "Sex" for Foucault does not have a cause for its distinction in thought without also involving an organization of its boundaries as a subject of truth with specific objects and practices. It is hard to know, therefore, what really can or cannot count as a production of pleasure that is organized under the significance of the word "sex" with any specificity. "Sex" and the recognition of what counts as sexual is itself a quagmire for principles of freedom and autonomy because the concept is historically deployed in situated social discourses as a subject of power (Foucault, 1990).

${ }^{3}$ Rubin discusses sex negativity, and identifies its multiple variations in close relation to Foucault's (1978/1990) History of Sexuality (p. 11). Rubin (1984/1993) organizes several different corollaries of moral hierarchies pertaining to a single ideal of sex with a main theme of sex negativity - the recognition of specific historical and cultural trends that treat sex suspiciously or inherently sinful. Negativity is first associated with "sexual essentialism" that privileges sex as a "natural force that exists prior to social life and shapes institutions" and as if it were an "eternally unchanging" force in life (p. 9). Rubin's second example is the "fallacy of misplaced scale", which refers to how sex acts can be burdened with an "excess of significance" (p. 11). Rubin points to a hierarchical valuation of sex acts that indicates a positive or negative attitude in relation to sex (p. 11). The moral presumption here is that the closer one is to monogamous, heterosexual,
} 
concepts does not, however, assure the actual outcome of heterosexual desire. Rather, categories of desire emerge as a discursive form of power that are tied to naming practices of the body's pleasures and worked to determine what counted as sexual feeling and sexual identity (Foucault, 1978/1990, p. 34). Sexual acts became fixed identities over a historical period of time, rather than how it was seized by scientists-of-modernity as a feature of some natural primordial order. Emphasizing this, Foucault writes about the distinction between a homosexual and heterosexual as a late $19^{\text {th }}$ century paradigm shift: "The sodomite had been a temporary aberration; the homosexual was now a species" (p. 43). Foucault argues that, as acts of resistance become necessary, there is a discursive production of the erotic- "spirals of power and pleasure" (p. 45). Sex became recognized as the expression of liberation from hierarchical relations, while even, at the same time, becoming discursively "circumscribed, incited, and intensified" by these discourses (Matrim, 2014). Foucault argues, "[The law] did not set boundaries for sexuality; it extended the various forms of sexuality, pursuing them according to lines of indefinite penetration" (cited by Matrim, 2014, p. 319).

Any prescription for schools to teach about a sex and sexuality treats sex as something worthy of social control and worthy for the concern of these institutions, but this is a problematic without end (Foucault, 1978, 1990). The practical and productive question for schools is how they can stop imposing this thing we call sex and sexuality upon students, while at the same time working to interrupt and decrease consistent patterns of persecution, exploitation, and violence.

The political flyer also warns that parental consent will not be sought for anti-homophobia curriculum, and that TDSB schools are being used by politicians to deliver a secret and sexualized curriculum to students. The $\mathrm{CH} \& \mathrm{H}$ resource is quite specific as to why parents are not asked to consent for their child, noting "if a school treats the topic of sexual orientation of anti-homophobic work differently from the range of other curriculum topics, this could be construed as a discriminatory practice" (TDSB, 2011, p. 10). Of course, parents are not entirely excluded insofar as they can participate in many layers of school governance. However, it is important to remember that discrimination is already reflected in the practices of the TDSB, since sex and gender minorities are rarely if ever represented to half or more of the board's students, despite a decade of anti-heterosexist and anti-homophobic policy. Discrimination and exclusion remains prevalent. Though the Board can hardly be faulted for its high aspirations and commitments, it now appears that neither parents nor students are consenting to the actual representation of sex, or anti-heterosexist curriculum at the TDSB. Sex negativity, heterosexist exclusion, and a relative lack of consent between parents, students, and the curriculum continue to be the problems at issue.

Another example which demonstrates the persistence of sex negativity, heterosexist exclusion and a lack of consent between students and curriculum can be found in a set of curriculum activities that were published within the $\mathrm{CH} \& \mathrm{H}$ documents. Note how sex, kissing, and other forms of sexualized affection are treated in this exercise:

Love is for Everyone: Valentine's Day-February 14th

Reclaim Valentine's Day and celebrate sexual diversity. Challenge your school to create an inclusive Valentine's Day.

\section{Kissing Booth}

Set up a tent or other structure, in a central place, that students and staff can enter. Decorate with cherubs and hearts. Put together a slide show of anti-homophobic messages and have it run on a continuous loop on a wall nearby. Before entering the Kissing Booth, students and staff must

reproductive sex-the presumed essential cause of sex — the closer one is to goodness. Then there is the domino theory of sexual peril. Sex acts are signified as either good or bad. Good sex is "sanctifiable, safe, healthy, mature, legal, or politically correct" (p. 14). Sex is always perceived to be negative if it is not heterosexual, but the extent to which sex is considered good or bad has more to do with moral evaluations that politicize sex rather than the extent of mutual pleasure. Heterosexual sex is described in "religious, psychological, feminist, or socialist" discourses as "exhibiting the full range of human experience" whereas "promiscuous homosexuality, sadomasochism, fetishism, transsexuality, and cross-generational encounters" can be singled out as devoid of the same range of human feeling as heterosexual sex (p. 15). 
complete a short 10-15 question school-climate survey. In the booth, students and staff are greeted by students who place a stamp of a kiss on their cheek and a few chocolate kisses in their hand. Extend the Kissing Booth activity by informing all home form teachers of the event, ask them to announce it and provide discussion questions for the day after. Publicize the results of the climate survey that kissing booth participants filled out. (TDSB, 2011, p. 142)

Rather than a bona fide kissing booth that is designed for actual kissing like the name of the activity implies, the activity provides an environment where stakeholders can complete a climate survey about homophobia and heterosexism. A climate survey raises awareness of differences among students because it teaches students to identify and recognize incidents and patterns of bias and exclusion. As a Valentine's Day climate survey for homophobia and heterosexism, it is an excellent activity. It appears, however, that the Valentine's Day Kissing Booth is not actually for kissing at all! There is a symbolic performance of kissing-a "stamp of a kiss", or rather an inked stamp of lips pursed together into a kissing shape, stamped on your cheek by front-door greeters. While the activity may appear to be harmless, students and sex are treated in a way that may be unhelpful.

Authorities sanction the space and they mark it by the use of the enclosed and compartmentalized space. The organization of the room, booth, or tent, coupled with the suggestion that this is where kissing occurs, and where positive sex and gender minority representation occurs, keeps all of these activities compartmentalized. This works to incite and teach a very particular form of recognition of what counts as sexual. Even if the most central classroom in a school were reserved for kissing, the very idea of a Valentine's Day Kissing Booth in school is an explicit organization of sex, kissing, and sex and gender minorities because it constructs a zone in the school where these relations require containment. Kissing is also not circulated as, for example, a way to express non-sexualized forms of intimacy, or as method for helping infants to ingest food. The activity will likely succeed in teaching children that kissing is sexually explicit, particularly because no one actually gets a kiss anyway.

Since youth do not consent to public schooling, have limited power to shape curriculum, and cannot legally consent to sexual relations by institutional command, this activity prevents making the act of kissing a group or class activity. The limitation of the activity may be appropriate, given that schools are charged with protecting children from sexual situations in which they cannot offer their legal consent, but note that the activity has nothing to do with negotiating consent. Students were not asked whether they want to receive the stamp of a kiss, nor is there any modeling of how to negotiate consent with someone else. Even though the activity attempts to showcase positive representations of intimacy, the desires and interests of students are completely ignored. Becoming subjected to a curriculum that treats kissing in a very particular way, while not providing a space for students to negotiate consent, and actually secure a kiss for Valentine's Day, is an example of how schools routinely treats sex as a negative subject and students as the 'subjects' of school control (Foucault, 1978/1990). The activity of the kissing booth cannot help but re-enact a very specific heterosexist cultural situation in which everything related to sex or sexuality is too negative and dangerous for students, despite this activity being an attempt at anti-heterosexist and anti-homophobic curriculum.

Though the activity may seek to queer Valentine's Day, the activity of the Valentine's Day Kissing Booth exposes students to the recognition of kissing as something explicit and dangerous, and deserving of authoritative control, prohibition, censorship, private and/or subversive spaces. Though it seeks to illuminate heterosexist forms of control that are enacted upon students in schools, the activity reiterates a negative and prohibitive concern around the intimacy associated with kissing and sex and gender inclusion. The activity can suggest that these representations are too explicit or sexual for regular school curriculum, and that sex and gender minorities can only be represented in a tent, but not elsewhere at school. Representations of sex and gender minorities may be revolutionary and powerful for some, but since the kissing booth happens only on Valentine's Day, this may treat the representation of sex and gender minorities as something particularly explicit and sexual. By disallowing any space for actual kissing on Valentine's Day, the activity may work to strip away any sex-positive politic from the trans*, lesbian, gay, and queer body, leaving only static images of kissing couples and identity-labels for student visibility.

I do not conceptualize the import of the kissing booth activity as wholly good or bad, as this is likely to be highly variable, depending on how the activity is adapted, but I point out the recurrent problems of how 
the curriculum turns sex (and everything that can attach to it) into a naughty subject of prohibition and censorship, and that subjects students to a top-down curriculum. ${ }^{4}$ Even while schools attempt to protect students from harmful messages about sex, students are subjected to a heterosexist curriculum that consistently excludes, and ignores any capacity that students have to consent to their own curriculum.

\section{A Radical Theory of Heterosexism at School}

Several theories of sex challenge the use of any hierarchy which can subject individuals, such as students, to a political order, and then minoritize them, and treat sex negatively. Rubin (1984/1993) once lamented the absence of a concept of benign sexual variation, and points to "variation" as a "fundamental property of all life...", such that no matter how sex is related to a "single standard", it will always be varied and cannot be expected to conform (p. 15). Rubin writes that "it is difficult to develop a pluralistic sexual ethics without a concept of benign sexual variation" (p. 15). Rubin's wish for a theory of "benign sexual variation" could be misunderstood to embrace all forms of sex whether they are violent or not, but a benign theory of sexual variation is only as useful inasmuch as it also denounces subjugation, violence, and coercion. Indeed, Rubin affirms this qualification:

A radical theory of sex must identify, describe, explain, and denounce erotic injustice and sexual oppression. Such a theory needs refined conceptual tools which can grasp the subject and hold it in view. It requires a convincing critical language that can convey the barbarity of sexual persecution. (p. 9)

The "barbarity of sexual persecution" is obviously not benign in its modes of production, or in social relationships. Since everyone is situated and subjected within the order of heterosexist identities and desires in some way, Rubin's wish for a "benign theory of sexual variation" must also be situated in a critical account of overcoming subjugation in thought and life, and denouncing persecution and prejudice in general. Deleuze's (1988) study on Spinoza offers some insight through a series of caricatures that explore the "sadomasochism of the tyrant-slave" (pp. 12,13). These caricatures help "convey the barbarity of sexual persecution" called for by Rubin because they show how heterosexist conditions in school contribute to persecution, violence, and other un-consensual relations.

Deleuze (1988) explains Spinoza's example of the three caricatures of the moralist trinity-the slave, tyrant and priest. Slaves cannot help but "allow all types of burdens to be placed on them"; the tyrant exerts power over others by forcing them to obey (p. 26). The caricature of the priest is altogether saddened by the human condition and teaches others to worship suffering, subjection, and enslavement. One should not take these caricatures too literally in determining who is a consistently a victim or a perpetrator. Even the tyrant and the priest are slaves of their own malice and hypocrisy, and they can both be tangled into affirming each other's subjective positions. Deleuze argues that what unites the slave, tyrant, and priest is a general hatred of humanity and resentment against life, and where "wretchedness or impotence" becomes passion (p. 25). These moralists are "hoodwinked" into upholding and affirming forces outside of existence, erroneous cause and effect relationships, and a singular, universal order of good and evil. Since the ideas and concepts of the sad caricatures are no longer grounded in a logical cause and effect relationship, and do not refer to real forces in existence, their lives are guided by inadequate ideas and "sad passions".

In the Deleuzian-Spinozian philosophy, an idea that is adequate and logical is also adequate for a life of freedom. Adequate ideas make sense and will go on to preserve the freedom of the individual. This good idea will make sense and interact with what someone already knows, and this will add to the joy, vitality, and free expression of a person and they will act with a certain degree of increased power. When a person encounters an inadequate and illogical idea, a "sad passion" would be immediate, because the bad idea would be rejected from thought. A bad and illogical idea would not fit in with someone's practical sense of how to preserve

${ }^{4}$ I realize that a pioneering curriculum may demand a particular degree of risk and experimentation. 
their capacity to act in freedom. If someone should not fully understand the consequence of subjection to the idea that they have encountered, but have taken this idea as true anyway, the idea can tie this person's 'thinking' to false causes. This person then goes on to have their freedom stolen and expressions of their freedom become perverted by this bad idea. This inadequate idea is characterized by a relationship of subjection and enslavement, and this turns the person against themselves and everyone else. ${ }^{5}$ Suddenly, bad ideas that only refer to enslavement might suddenly seem like good ideas, and this error in thought can compound the "sad passions" that this individual is likely to experience. Each body can only strategically coordinate with the thought-events that happen to it. As such, if someone does not understand the relations of subjection that are embedded within the concept that they encounter, this person can become an unwitting caricature of the sad passions (Deleuze, 1988).

Consider the sometimes tyrant, sometimes priest, and sometimes enslaved, subject-position of heterosexual male identity. This identity is historically privileged by the signification of gender and sex hierarchies to adopt the role of the tyrant. Heterosexual man is not necessarily free to become just anything, however, because the individual body, when gendered as a male, becomes affirmed by a transcendent order of gender that asserts "maleness" as its cause. Men are also situated as "slaves" to the heterosexist order that treats gender as a transcendent cause of heterosexual desire, or the "heterosexist matrix" (Butler, 1993). The individual body, gendered as male, is situated to use its gendered identity as a political strategy in social relationships that are situated in moral discourses, such as heterosexism. 'Men' are most often enslaved to the historical, social, economic, and political circumstances that work to legitimate their performances of domination (priests/tyrants) as the ground of their "being". Men are perhaps continually privileged to adopt the roles of tyrant and priest in relation to other gendered bodies because heterosexist discourses signify masculinity as dominant over femininity. This increases the probability that male-identified bodies will seek to dominate some feminized 'other' in social relationships, but this in no way assures that this will occur either, because we are all situated within globally disparate heterosexist discourses, and each of us becomes subjected by this situation in different ways.

A lack of consent between students and heterosexist logic leads to social relationships that also lack consent. The idea of a single ideal for sex, formed within the moral order of heterosexism, takes the shape of exclusion and sex negativity. In schools, this idea works to produce the recognition of sex as a set of relationships that can impose upon people. Any potential capacity for students to consent to a curriculum with information about sex is not even considered. The moral logic of heterosexism-its hierarchical orders of good and evil, identities, labels and presumed universality-robs all students of their autonomy and freedom in some way (Rubin, 1984/1993). Heterosexist environments are instructive, and schools produce sexuality among students in very particular ways. When the metaphor of the sad caricatures is interpolated with heterosexist forms of exclusion, particularly with those that become intensified within TDSB school curriculum, it suggests that heterosexist forms of bias can promote the production of "sad passions" throughout our social relationships by creating sad characters within each of us. The predator-rapist, abuser, bully, misogynist, and homophobe perhaps best exemplify the tyrant. The priest reappears as the schoolteacher of an authoritative curriculum who teaches about sex as if it requires negativity, social exclusion, chastity, and conversion therapy.

The example of the slave is anyone and everyone situated in moral discourses of Western sexuality (Deleuze, 1988). In particular, the incited, enslaved, strategic, and rebellious student is subjected to a topdown curriculum at the same time that he or she or they are situated in heterosexist conditions. Such morally affected students are disempowered from organizing their desires with tolerability because their being is formulated by the institution as if it were a transcendent property that refers to a categorical notion of gender and sex. Students do not consent to their gender, race, sexuality, or how these matters become signified in heterosexist social conditions, but rather students are thrown like "dice" into these hierarchical social

\footnotetext{
${ }^{5}$ Deleuze (1988) specifies that any activity that comes from "sad passions" is itself a re-enactment of how the body is acted upon by bad ideas (p. 50). Illogical ideas cannot truly join with the power of the individual, but rather they impose on the individual ideas that do not make sense and can only require submission. Worse, these ideas become enacted through the individual in their relationships with other people and other ideas and they cause harm.
} 
situations and become strategic performers in these circumstances (Deleuze, 2006, p. 25; Butler, 1993).

Understanding how people are situated amidst forces of thought that act upon them, without their consent in some circumstances, can also help to answer questions such as how people continue to have unprotected sex, how gender-based violence can be so persistent, how people with known sexually transmitted illnesses can continue to put others at risk, how people can claim that they are not "in control" of their desires, how sex addiction can become possible, how people can have and exercise 'unwanted' desires, and how people can spread hatred, tyranny, secrecy, malice, persecution, and judgment. When pleasure becomes coupled to the force of an idea that subjects us to power, rather than becoming part of our own power to act in freedom, it can be profoundly habitual. Heterosexist discourses affect us in ways that can be unconscious to us, but generally a reciprocal relationship between thought and the capacity of a body to act correlates to the quality of reciprocation that this same body can have in its social relationships. The metaphor of the moralist trinity presents a model of intensities, variability, and thresholds rather than defined outcomes because there are so many different ideas and relationships that make up each life (Matrim, 2014).

\section{Conclusion}

Citizens of Toronto and Ontario have debated sex education for over a century, but most of the interventions from policy have largely been confined to reimagining how curriculum can force students to learn about something else. ${ }^{6}$ It is only in the past two decades that gay-straight alliances and other sex-positive student clubs have finally become sanctioned, if not also quietly mandated by the TDSB. Theories of sex and gender from Foucault, Butler, and Rubin are helpful in assessing the import of some of the more politicized and controversial examples from the new TDSB anti-discrimination curriculum for sex and gender minorities. The structural relationship of a top-down curriculum remains problematic for instructing anything about sex because schools consistently treat sex prohibitively, and exclude the representation of sex and gender minorities in a contradictory effort to protect students from harm.

The caricatures of the moralist trinity from Deleuze's work on Spinoza were cited to illustrate the harm that comes from heterosexist conditions in schools. Heterosexist discourses were shown to refer to

${ }^{6}$ Cristabelle Sethna's (1995) doctoral dissertation, The Facts of Life: The Sex Instruction of Ontario Public School Children 1900 1950, provided a history of several distinct social circumstances in which sex education was realized differently as an urgent requirement for appropriate sexual development in children. Films, curriculum materials, conference notes, and public meetings were provided as Sethna's (1995) key source materials. Sethna (1995) argued that sex instruction was heavily influenced by a late nineteenth century social purity movement that was racist, classicist, and paternalistic (p. 3). Though sex instruction was internationally conceived by feminist, medical, legal, educational, and religious discourses, "the child ignorant of sexual matters, the feeble minded child, and the juvenile delinquent" were frequently "classed, gendered, (and) racialized" and the main targets for securing the population against venereal disease (pp. 2 , 5). Perhaps the most stable feature across this time period was the failure of sex to leave the private domain, in the context of it becoming a public education. Sexuality was viewed as a prolific force to be constrained from all sides, until heterosexual, monogamous, marriage, and hence only mothers and faithful fathers within private family relationships were beyond suspicion and imagined as exclusively capable to teach children about sex effectively. While sexual repression was not always viewed as a positive way to combat venereal disease, sexual knowledge was to be encoded by nature studies or inferences from scientific literature in order to be publicly appropriate. Sexual behaviour was always dubious, if not criminal, outside of heterosexual, monogamous, marriage. Most explicit perhaps, is that sex education for all of its 'natural' proscriptions, was not treated as a natural destiny, but rather naturalized by appropriate environments and lessons. The sex education debates over 60 years, as documented and interpreted by Sethna, revealed an adult preoccupation with how to manufacture a mythical 'natural' moral order from the production of individual heterosexual, monogamous, subjects, and for the purposes of insulating the traditional family structure. Another resource I used for historical information was from educator and scholar Tim McCaskell (2005). As an employee of the TDSB, straddling job duties in policy creation, community development, and coordinating anti-discrimination activities, McCaskell documented his experiences in Race to Equity: Disrupting Educational Inequality (2005). His history is a guide to recent developments since the 1960's in anti-discrimination policy at the TDSB; in it he describes how many government policies have addressed the inclusion of sex and gender minorities and shaped the Board's activities. 
ideals that act upon students without their consent, and to promote the production of "sad passions", which is a way of referring to sexualized violence, self-hatred, and persecution, and other bad feelings that may be beyond the moralists' capacity to organize differently.

In previous works I pointed to the distinction of morals and ethics as a critique that can help develop a critical awareness among all stakeholders, but if schools are to practice this theoretical distinction, all stakeholders must also model the acquisition of consent from students, and respect a student's capacity to consent or not, throughout curriculum (Matrim, 2013a; 2013b, 2013c, 2014). Only by seeking consent from students could a curriculum of erotic freedom and justice ever be initiated or practiced. The consequences of heterosexist forms of exclusion and sex negativity remain tangible, and schools are already playing a significant role to both resist and reenact these practices. Along with grassroots and student led initiatives, curricula can help to combat the imposition of heterosexist situations in schools by illuminating relationships of subjection, modelling consent, and supporting more student governance.

\section{Acknowledgments}

Excerpts related to the current policies, census data, and curriculum have been variously discussed in such presentations as "A cautious intervention to the production of a subversive sex in public schools" at Queer U 2013, University of British Columbia, "A philosophy of sexual reciprocity for secular public schools of Toronto" at American Education Research Association 2013 Annual Meeting, San Francisco, CA, and "Promoting sexual reciprocity in schools with the distinction between morals and ethics" at the Canadian Society for the Study of Education (CSSE) 41st Annual Conference 2013, Victoria, British Columbia (Matrim, 2013a; Matrim, 2013b; Matrim, 2013c). Themes related to older TDSB data, and different analysis with Foucault (1978/1990) and Deleuze (1988) is published in "A theory of sexual reciprocity for democratic classrooms" in The Handbook of Gender and Sexualities in Education (2014) edited by D. Carlson and E. Meyer (New York: Peter Lang Publishing). Original Master's thesis research was conducted in 2012, entitled The Distinction of Morals and Ethics: Discourses of Sex That Reciprocate With Students' Learning Needs, University of Toronto. Thanks to my family, friends, and the scholars, research subjects, and participants, of the theories, policies and studies that I cite, the Philosophy of Education programme at Ontario Institute for Studies in Education at University of Toronto (OISE/UT), to the School of Graduate Studies at University of Toronto, OISE/UT and the Ministry of Education and Training of the Province of Ontario and the citizens of Ontario and Canada. Sexual Diversity Studies programme at University of Toronto and its faculty 2000-2005, with special thanks to professors Maureen Fitzgerald and Scott Rayter. Thanks to the crew of the Sexual Assault Support Centre@ University of British Columbia. Thanks to professors Maureen Ford, Megan Boler, Trish Salah, Etienne Turpin, Roy Gillis, Heather Sykes, Ruth Sandwell, Peter Stickney, Rinaldo Walcott, and scholars Virginia Stead and Tim McCaskell. Special thanks for editing support from Roz Spafford and Mary Anne Carswell.

\section{References}

Butler, J. (1990). Gender trouble. New York: Routledge.

Butler, J. (1993). Imitation and gender insubordination. In H. Abelove, M.A. Barale, and D.M. Halperin (Eds.), The Lesbian and gay studies reader (pp. 307-320). New York, NY: Routledge.

Canadian Press. (2011, October 3). Ontario PC's grilled over flyer called anti-gay. CBC News. Retrieved from http://www.cbc.ca/news/canada/toronto/story/2011/10/03/ontario-parties-campaignminority $274 . h t m l$

Deleuze, G. (1988). Spinoza: Practical pbilosophy. San Francisco, CA: City Lights Books.

Deleuze, G. (2006). Nietzsche and philosophy. New York, NY: Columbia University Press.

Flicker, S., Flynn, S., Larkin, J., Travers, R., Guta, A., Pole, J., \& Layne, C. (2009). The Toronto teen survey report. Planned Parenthood Toronto. Toronto, ON: Sexpress.

Foucault, M. (1978/1990). History of sexuality: An introduction (Vol. 1). (R. Hurley, Trans.). New York, NY: Vintage Books.

Matrim, J. (2012). The distinction between morals and etbics: Discourses of sex that reciprocate with students' learning needs within the Toronto District School Board and other secular school boards of Ontario (Master's thesis). University of Toronto, Toronto. 
Matrim, J. (2013a). Promoting sexual reciprocity in schools with the distinction between morals and ethics. Paper presented at the Canadian Society for the Study of Education 41st Annual Conference 2013, Victoria, BC.

Matrim, J. (2013b). A pbilosopby of sexual reciprocity for secular public schools of Toronto. Paper presented at the American Education Research Association 2013 Annual Meeting, San Francisco, CA.

Matrim, J. (2013c). A cautious intervention to the production of a subversive sex in public schools. Paper presented at Queer U 2013, Vancouver, BC.

Matrim, J. (2014). A theory of sexual reciprocity for democratic classrooms. In D. Carlson \& E. Meyer, Eds.), The handbook of gender and sexualities in education (pp. 313-327). New York, NY: Peter Lang Publishing, Inc.

McCaskell, T. (2005). Race to Equity: Disrupting Educational Inequality. Toronto: Between the Lines.

Rubin, G. (1993). Thinking sex: Notes for a radical theory of sexuality. In H. Abelove, M.A. Barale, \& D.M. Halperin (Eds.), The lesbian and gay studies reader (pp. 3-44). New York, NY: Routledge.

Safe Schools Action Team. (2008). Shaping a culture of respect in our schools: Promoting safe and healthy relationships. Toronto, ON: Ontario Ministry of Education.

Sethna, C. (1995). The Facts of Life: The Sex Instruction of Ontario Public School Children 1900-1950. Toronto: National Library of Canada.

Sexual Assault Support Centre. (n.d.). Got consent? Sexual Assault Support Centre at UBC. Retrieved on May 15, 2014 from http://www.gotconsent.ca/got-consent-campaign.html

Toronto District School Board \& Elementary Teachers of Toronto. (2002). Rainbows and triangles: A curriculum document for challenging homophobia and heterosexism in the K-6 classroom. Toronto, ON: Toronto District School Board.

Toronto District School Board. (2005). Equity foundation statement \& commitments to equity policy implementation. Toronto, ON: Toronto District School Board.

Toronto District School Board. (2011). Challenging homophobia and heterosexism: A K-12 curriculum resource guide. Toronto,ON: TDSB Equitable and Inclusive Schools.

Yau, M. \& O’Reilly, J. (2007). 2006 student census, Grades 7-12: System overview. Toronto, ON: Toronto District School Board.

Yau, M. \& O’Reilly, J. (2012). 2011 student census, Grades 7-12: System overview. Toronto, ON: Toronto District School Board.

\section{About the Author}

Jair Matrim is Mark S. Bonham Centre for Sexual Diversity Studies, University College, University of Toronto alumnus (2005), and MA graduate of the History and Philosophy of Education programme at OISE/UT (2012). He can be reached at jair.matrim@alum.utoronto.ca. 